\title{
NOCTURNAL AEROSOL PARTICLE FORMATION IN THE NORTH CHINA PLAIN
}

\author{
S. Kecorius ${ }^{\text {a,b }}$, S. Zhang ${ }^{b, c, d}$, Z. Wang ${ }^{\text {b,e }}, J$. Größ ${ }^{b}$, N. Ma ${ }^{b}$, Z. Wu ${ }^{\text {f }}$ L. Ran ${ }^{c}$, M. Hu ${ }^{\text {f }}$, \\ P. Wang ${ }^{c}$, V. Ulevičius ${ }^{a}$, and A. Wiedensohler ${ }^{b}$ \\ ${ }^{a}$ Center for Physical Sciences and Technology, Savanoriu Ave. 231, LT-02300 Vilnius, Lithuania \\ ${ }^{\mathrm{b}}$ Leibniz Institute for Tropospheric Research, Leipzig 04318, Germany \\ ${ }^{c}$ Key Laboratory of Middle Atmosphere and Global Environment Observation, Institute of Atmospheric Physics, Chinese \\ Academy of Sciences, Beijing 100029, China \\ ${ }^{\mathrm{d}}$ Chengdu University of Information Technology, Chengdu 610225, China \\ ${ }^{e}$ Multiphase Chemistry Department, Max Planck Institute for Chemistry, Mainz 55128, Germany \\ ${ }^{\mathrm{f}}$ College of Environmental Sciences and Engineering, Peking University, Beijing 100871, China \\ E-mail: ma@tropos.de
}

Received 13 October 2014; revised 10 November 2014; accepted 10 December 2014

\begin{abstract}
New particle formation is one of the major sources of atmospheric aerosol particles. Beside daytime nucleation, nocturnal new particle formation was also found in different regions around the world. Compared with daytime nucleation events, the understanding of nocturnal ones is still sparse. The variety of aerosol particle physico-chemical properties, including particle number size distribution, volatility and hygroscopicity were measured in the North China Plain during July-August 2013. During the observation period, rapid increase in ultrafine particle number concentration was attributed to new particle formation. The nocturnal new particle formation rate was $45 \mathrm{~cm}^{-3} \mathrm{~s}^{-1}$, which is 1.25 times higher than an observed daytime value. Condensation sink was found to be $0.055 \mathrm{~s}^{-1}$.
\end{abstract}

Keywords: nocturnal nucleation, particle number size distribution

PACS: $92.60 . \mathrm{Mt}$

\section{Introduction}

Aerosol particles are accused of both Earth's radiation budget uncertainties and adverse health symptoms [1,2]. These particles are the result of complex natural and anthropogenic processes, which set the challenge to characterize their properties and impact on environment. In parallel to the direct aerosol sources, atmospheric new particle formation (NPF) by nucleation from gaseous precursors is still the subject of intense experimental and modelling studies [3], 4. Nucleation events have been observed at different atmospheric environments around the world [3]. It is shown that nucleation occurs only when particle surface area concentrations are below a critical value $\left(2000 \mu \mathrm{m}^{2} \mathrm{~cm}^{-3}\right)$ [5]. Elevated concentrations of $\mathrm{SO}_{2}$ and $\mathrm{H}_{2} \mathrm{SO}_{4}$ were found to correlate well with the occurrences of nucleation events [ 6 ]. Laboratory experiments showed that volatile organic compounds might also play an impor-

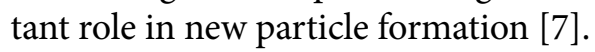

As NPF is usually observed during the daytime, it is emphasized that it occurs because of low preexisting particle mass concentration and photochemical production of gaseous precursors [8]. However, many scientists have also reported nocturnal nucleation events [9, 10, 11]. Daytime nucleation pathways do not apply to nocturnal nucleation, since $\cdot \mathrm{OH}$ radical, the major precursor of binary and ternary nucleation, is the photochemical product of ozone and water [12, 13]. Moreover, during nighttime, local emissions are trapped in the low boundary layer leading to a higher condensation sink 14.

The importance of ozone and monoterpenes in nocturnal NPF events has been showed in Tumbarumba, Australia [15]. In polluted environments $\mathrm{SO}_{2}$ conversion to $\mathrm{H}_{2} \mathrm{SO}_{4}$ might take place throughout $\mathrm{NO}_{3}[16]$. Compared with daytime nucleation events, the understanding of nocturnal ones is still sparse. The exact molecular mechanisms and participating vapours causing atmospheric nucleation events are still open to discuss. 
A better understanding of this phenomenon would help to improve climate models, the knowledge about their direct scattering of solar radiation as well as the indirect effects on climate throughout the increase in the number of cloud condensation nuclei (CCN) [17].

In this study we present ground-based atmospheric observations which indicate new particle formation occurring during the night. Particle number size distribution, size-resolved volatile and hygroscopic properties of aerosol particles were measured at the most polluted province in China, Hebei, at a regional Xianghe site in the framework of "Campaigns of Air Quality Research in Beijing and Surrounding Region 2013" (CAREBeijing-2013). The goal of this study was to identify possible, locally distributed precursors for nocturnal new particle formation events observed in the North China Plain.

\section{Experiment}

\subsection{Measurement site}

Aerosol physical properties were explicitly measured at a suburban site in Hebei province $\left(39.75^{\circ} \mathrm{N}, 116.96^{\circ} \mathrm{E}\right)$, China, roughly $70 \mathrm{~km}$ south-eastward from Beijing. Hebei province encloses two densely populous cities: Tianjin, a major seaport, and Beijing, the capital city of the People's Republic of China. The large industrial production contributes seven of the ten highest polluted cities in China located in this province [18]. The measurements were performed as a part of the CAREBeijing-2013 measurement campaign during July 8 to $\mathrm{Au}$ gust 9,2013 . The measurement containers were located about $5 \mathrm{~km}$ to the west of Xianghe town center (Fig. 1). The surroundings of the Xianghe site are mainly resi- dential rural areas. During the measurement campaign the median nighttime relative humidity $(R H)$, temperature $(T)$, wind direction $(w d)$ and speed $(w s)$ were $R H=96.6 \%, T=23.2^{\circ} \mathrm{C}\left(\min : 19.6^{\circ} \mathrm{C}\right.$, $\left.\max : 27.6^{\circ} \mathrm{C}\right)$, $w d=$ west-northwest and south-east, $w s=0.4 \mathrm{~m} \mathrm{~s}^{-1}$, respectively. Mean daytime corresponding values were $R H=75.2 \%, T=27.5^{\circ} \mathrm{C}\left(\min : 20.5^{\circ} \mathrm{C}, \max : 36.5^{\circ} \mathrm{C}\right)$, $w d=$ south-west, north-west, $w s=1 \mathrm{~m} \mathrm{~s}^{-1}$.

The aerosol sampling line was constructed to consist of a PM 10 inlet (Rupprecht \& Patashnick Co., Inc., Thermo, $16.671 \mathrm{~min}^{-1}$ ), three in-line SS24 Perma Pure Nafion dryers and an aerosol drying chamber with an alternate regenerating set of two silica gel diffusion driers [19]. This set-up ensured an aerosol sample with a low relative humidity $(<30 \%)$, which was indispensable for different aerosol measurement comparability. In a measurement container (air conditioned to $24{ }^{\circ} \mathrm{C}$ ), the sampled air was fed to separate instruments through stainless steel/conductive tubes using an isokinetic flow splitter.

\subsection{Instrumentation}

\subsubsection{Measurements of aerosol particle number size distribution}

A Scanning Mobility Particle Size Spectrometer (SMPS, TROPOS, Leipzig, Germany) was used to measure the aerosol number size distribution [20]. The system consists of a Hauke-type $(28 \mathrm{~cm}$ effective length) differential mobility analyzer (DMA) and a condensation particle counter (CPC, model 3025, TSI, Inc., Shoreview, MN USA) to measure particles in a range from about 10 to $800 \mathrm{~nm}$. The ratio between sheath and aerosol flow was 5:1 $1 \mathrm{~min}^{-1}$. The

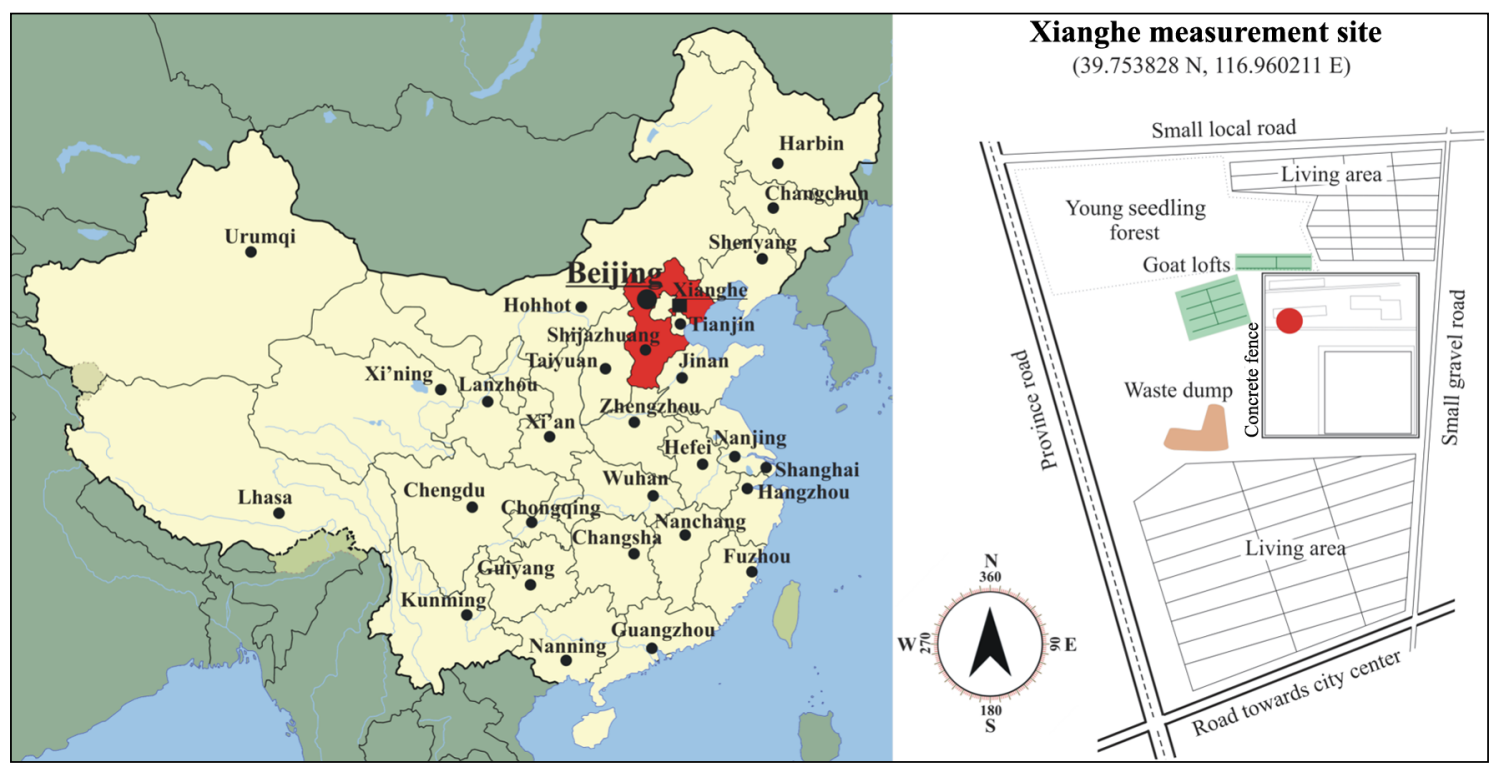

Fig. 1. Xianghe measurement site. Red spot indicates the position of measurement container in the site. 
time resolution of the SMPS was set to 5 minutes. In addition to the SMPS, the measurement set-up included a Nano-Aerosol and Air Ion Spectrometer (NAIS, Airel Ltd., Tartu, Estonia) [21]. The NAIS was established to measure the mobility distribution of air ions and ultrafine aerosol particles $(2-20 \mathrm{~nm})$. The controlled unipolar charging of aerosol particles together with the electrical filtering of ions enables to detect aerosol particles and to distinguish them from air ions. The mobility range of the NAIS is 2.4$0.0010 \mathrm{~cm}^{2} \mathrm{~V}^{-1} \mathrm{~s}^{-1}$ [22], which corresponds to a mobility diameter range from 0.9 to $47 \mathrm{~nm}$. The NAIS data were averaged to 5 minutes.

\subsubsection{Measurements of aerosol particle hygroscopicity}

Hygroscopic properties and the mixing state of atmospheric aerosol particles were determined with a Hygroscopicity Tandem Differential Mobility Analyzer (H-TDMA, TROPOS, Leipzig, Germany) [23]. Only the basic operating principles are discussed here. The H-TDMA is made of two Hauke-type (28 cm effective length) DMAs, two CPCs (model 3010, TSI, Inc., Shoreview, MN USA) and a humidification section. A dried, neutralized and quasimonodisperse aerosol particle fraction, selected by the first DMA, is fed into a humidification section, where the particles are conditioned to a relative humidity of about $87 \%$ and grow up due to water vapour condensation. Afterwards the number size distribution of these particles is measured using the second DMA accompanied with a CPC. The humidifiers and the second DMA are kept in a thermo isolated box to minimize temperature fluctuations. The periodically measured hygroscopic growth of ammonium sulfate (every 6 hours) was used to calibrate the $R H$ inside the second DMA [24]. The time resolution for five dry particle sizes $(50,100,150$, 250 and $350 \mathrm{~nm}$ ) was approximately about $50 \mathrm{~min}$ utes.

\subsubsection{Measurements of aerosol particle volatility}

The refractory aerosol fraction was measured using a TROPOS-type Volatility Tandem Differential Mobility Analyzer (V-TDMA) [25]. The operation principle is similar to that of the H-TDMA with only one difference - in the conditioning unit the humidifiers are replaced by volatilization columns, where volatile compounds (sulfates, nitrates and most of the volatile organic carbon) are evaporated at $300{ }^{\circ} \mathrm{C}$ revealing non-volatile particle cores of a certain diameter [26]. The system consists of two Hauke-type (11 cm effective length) DMAs, two CPCs (TSI model $3760 \mathrm{~A}$ ) and a thermo denuder consisting of vola- tilization columns. As in the H-TDMA system, the V-TDMA measurement cycle can be arranged into three steps. First, a quasi-monodisperse particles fraction is selected by the first DMA. In the second step, the selected particles pass the volatilization columns, where the temperature is set to $300{ }^{\circ} \mathrm{C}$, where the volatile particle fraction is removed by thermal desorption. After all, the residual particle number size distribution is measured by the second DMA and CPC. The measurement time resolution including five particle sizes $(50,100,150,250$ and $350 \mathrm{~nm})$ was adjusted to about one hour. The residence time of the particles in the heating column was $0.5 \mathrm{~s}$, which is sufficient enough to vaporize the particle fraction in the narrow size range [25]. Brownian diffusion and thermophoresis induced particle losses effect on transport efficiency were measured using sodium chloride $(\mathrm{NaCl})$ under laboratory conditions. Species which did not evaporate at the highest temperature of $300^{\circ} \mathrm{C}$ were referred as refractory in this study.

\subsubsection{Measurement of expected nucleation \\ precursor species}

Ambient $\mathrm{O}_{3}$ concentration was measured using a nondispersive ultraviolet (UV) photometer (EC9810B, ECOTECH, Australia). $\mathrm{NO}$ and $\mathrm{NO}_{x}$ concentrations were measured using the oxides of a nitrogen analyzer (EC9841B, ECOTECH). The technique is based on a heated molybdenum $\mathrm{NO}_{2}$ to $\mathrm{NO}$ converter and chemiluminescence. The concentration of $\mathrm{SO}_{2}$ was measured using a pulsed UV fluorescence analyzer (EC9850B, ECOTECH). Calibrations were performed using the standard reference gas mixtures. The recommendations on quality assurance and quality control were provided by the United States Environmental Protection Agency.

\subsection{Methods}

\subsubsection{Nucleation rate and condensational sink}

The aerosol particle nucleation rate and condensational sink formalism was taken from Dal Maso et al. [27]. For detailed information, please refer to the mentioned source. The nucleation rate, $J_{\text {nuc }}$ can be expressed as

$$
J_{\text {nuc }}=\frac{\mathrm{d} N_{\text {nuc }}}{\mathrm{d} t}+F_{\text {coag }}+F_{\text {growth }},
$$

where $N_{\text {nuc }}$ is the number concentration of nucleation mode particles, $F_{\text {coag }}$ is the loss of newly formed particles due to coagulation, and $F_{\text {growth }}$ is the flux of particles out of the specified size range. In this study, 
we calculated only the lower nucleation rate value excluding $F_{\text {coag }}$ and $F_{\text {growth }}$. This was enough to distinguish between daytime and nighttime values. The particle condensational sink, $C S$, can be calculated using

$$
C S=2 \pi D \sum_{i} \beta_{\mathrm{M}} D_{\mathrm{p}, i} N_{i},
$$

where $D$ is the diffusion coefficient, $\beta_{\mathrm{M}}$ is the transitional correction factor for the mass flux, $D_{\mathrm{p}, i}$ is the particle diameter, and $N_{i}$ is the particle number concentration in the size bin $i$.

\subsubsection{Growth factor probability density function}

Thorough methodology for V-TDMA data evaluation is presented in Cheng et al. [28]. The same approach was also implemented for H-TDMA. The measured mobility spectra were corrected by taking into account charging probabilities, counting efficiency of the condensation particle counter, transfer function, diffusion and thermophoresis losses [29]. Measured V-TDMA and H-TDMA distributions were inverted using the TDMAinv routine [30]. The hygroscopic growth factor $(G F)$ refers to a ratio between the particle mobility diameter, $D_{\mathrm{p}}(R H)$, at a given $R H$ and the dry diameter, $D_{\mathrm{p}, \mathrm{dry}}$ :

$$
G F(R H)=\frac{D_{\mathrm{p}}(R H)}{D_{\mathrm{p}, \text { dry }}} .
$$

The shrink factor $(S F$ or $G F<1$ ) is defined by the ratio between the mobility diameter at a temperature of $300^{\circ} \mathrm{C}$ and $25^{\circ} \mathrm{C}$. Before the inversion of the measured distributions, the size shift correction was established. In addition to the H-TDMA data, the ammonium sulfate $R H$ calibration was applied. The GF probability density function (GF-PDF) was integrated in a range from 0.8 to 1.2 and 1.2 to 2.5 to identify hydrophobic and hydrophilic aerosol particle number fractions, respectively. The SF-PDF was integrated in a range from 0 to 0.8 and 0.8 to 1.4 to find the refractory and the volatile particle number fractions, respectively.

\section{Results and discussion}

In the CAREBeijing-2013 campaign, the data set comprises 32 days of continuous measurements of aerosol particle properties. During the measurement period, nocturnal new particle formation events were observed on $59 \%$ of the nights in a discrete manner without the pronounced subsequently following particle growth.

\subsection{Classifying the nocturnal NPF events}

The NPF classification is usually based on the visual inspection of the distinct shape of the formation and growth in the observed particle number size distribution (PNSD) contour plots [31]. In NPF studies, "non-banana-type" cases are regarded as "undefined" events [32]. The nocturnal nucleation events cannot be characterized as well-known particle formation with the "banana-shape" growth. Therefore we differ them according to the increase of the nucleation mode particle number concentration $(2-10 \mathrm{~nm})[6]$ and the specific particle volatility as well as the hygroscopic behavior (e. g. particles are completely volatile). The contour plot of the PNSD during one of the events is shown in Fig. 2. The contour plot is a combination of the data measured with the NAIS (PNSD between 2 and $15 \mathrm{~nm}$ ) and with the SMPS (PNSD between 15 and $800 \mathrm{~nm}$ ). In Fig. 2 the rapid increase of the nucleation mode particle number concentration, lasting between 20 and 50 minutes, is followed by a subsequent decrease.

During nighttime NPF events, the ultrafine particle number concentration $N_{2-10 \mathrm{~nm}}$ increased up to around $7.3 \cdot 10^{4} \mathrm{~cm}^{-3}$ and was at the same order of magnitude as during the observed day time events $\left(N_{2-10 \mathrm{~nm}}=7.5 \cdot 10^{4} \mathrm{~cm}^{-3}\right)$. The formation rate of the nocturnal new particle formation event (particles in the size range from 2 to $10 \mathrm{~nm}$, the loss of formed particles due to growth and coagulation is excluded) was 1.25 times higher than during the daytime event $\left(45 \mathrm{~cm}^{-3} \mathrm{~s}^{-1}\right.$ versus $\left.36 \mathrm{~cm}^{-3} \mathrm{~s}^{-1}\right)$. The average condensation sink CS for the particles in the range between $2 \mathrm{~nm}$ and $750 \mathrm{~nm}$ during the nocturnal NPF was found to be around $0.055 \mathrm{~s}^{-1}$. It is higher than the ones observed in Beijing, China (between $0.02 \mathrm{~s}^{-1}$ and $0.045 \mathrm{~s}^{-1}$ ) by Wu [6]. The nocturnal NPF occurring at a given high condensation sink implies extreme conditions, which differ from the daytime. It suggests that a new particle formation occurs not only when the particle surface concentration is high but also shows other processes to take part in a new particle formation.

\subsection{Aerosol particle volatility and hygroscopicity during nocturnal NPF}

The averaged measurement distribution functions (MDF) of V-TDMA and H-TDMA have shown that particles between 20 and $35 \mathrm{~nm}$ (operating limit for V-TDMA and H-TDMA, respectively) were highly volatile (the total refractory particle number fraction was $5 \%)$ and slightly hygroscopic $(G F=1.15)$ 


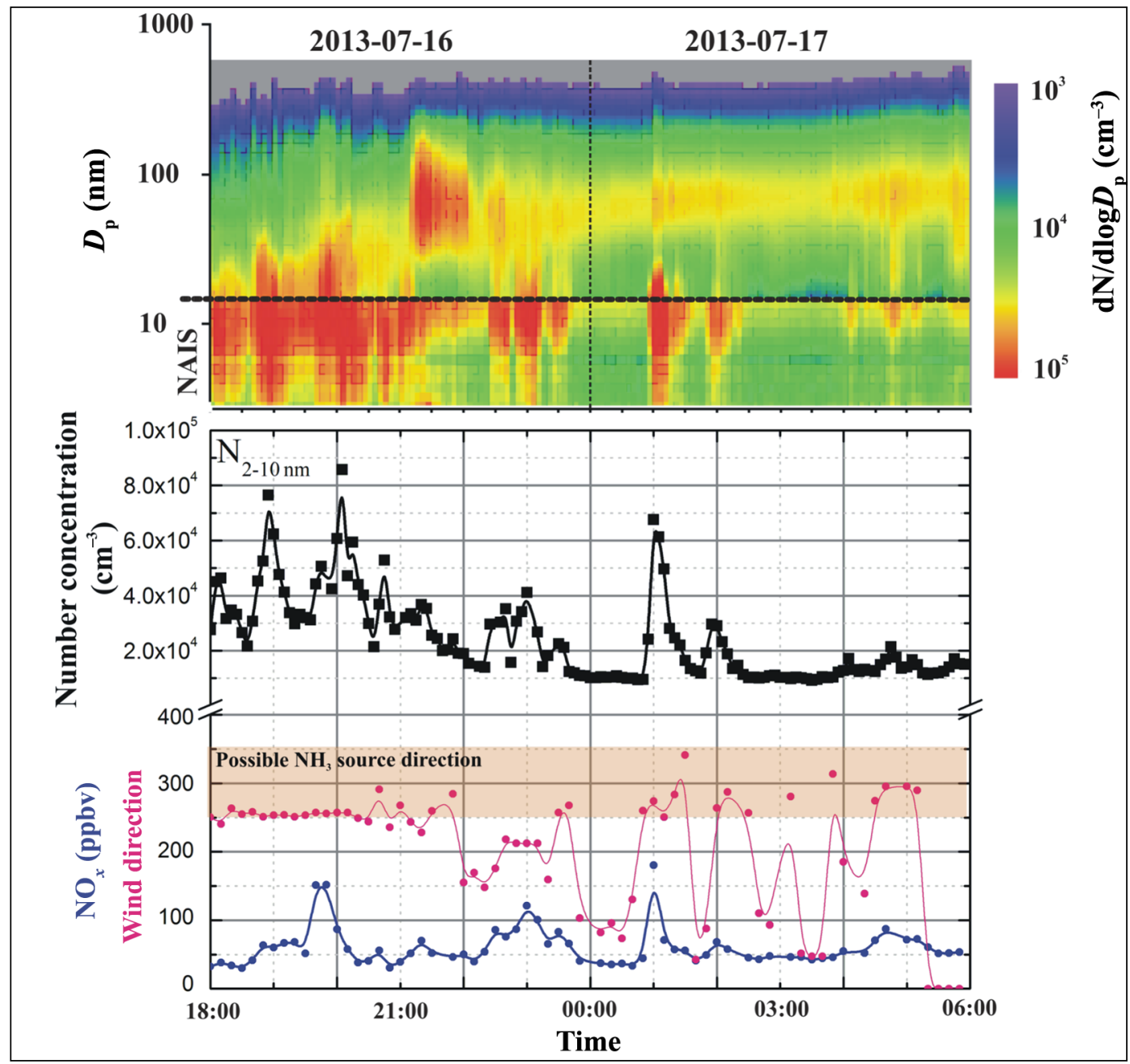

Fig. 2. Contour plot of the aerosol particle number size distribution, the nucleation mode particle number concentration $(2-10 \mathrm{~nm})$, the $\mathrm{NO}_{x}$ concentration and the wind direction for the nighttime from July 16 to July 17,2013 . The horizontal line marks the border between the NAIS $(2-15 \mathrm{~nm})$ and the SMPS (15-800 nm) PNSD contour plots.

(Fig. 3). V-TDMA PNSD measurements of $20 \mathrm{~nm}$ and H-TDMA PNSD measurements of $35 \mathrm{~nm}$ sized particles showed a significant increase in the MDF (mode maximum reached over 800 ) during nucleation episodes compared to non-event cases (nonevent cases refer to a MDF < 300). During the NPF episode the particles were conditioned in the $300^{\circ} \mathrm{C}$ environment - only minuscule refractory fraction (GF-PDF in Fig. 3) with a great uncertainty due to poor counting statistics remained.

The thermal conditioned particles were measured in the range between 9 to $23 \mathrm{~nm}$. In the H-TDMA system, $35 \mathrm{~nm}$ sized particles experienced a unimodal growth $(G F=1.15)$ when they are exposed to $R H$ of $87 \%$. The poor affinity of ultrafine particles to absorb water vapour can be explained by the Kelvin (curvature) effect, a major limitation in the growth of atmospheric nanoparticles, when significantly el- evated equilibrium vapour pressures above the small clusters limit its growth. However, our observed change was enough to distinguish between different aerosol particle mixing states, revealing the episodes when particles were newly formed. Since V- $\left(25^{\circ} \mathrm{C}\right)$ and H-TDMA MDFs are narrow enough, inverted GF-PDF can be represented using only MDF itself [300] and thus GF-PDFs for V- and H-TDMAs are not present in Fig. 3 .

\subsection{Possible precursors for the nocturnal NPF}

The wind direction during nocturnal NPF events was mainly between $250^{\circ}$ and $350^{\circ}$ (west-northwest). Wind speeds during the events were below $1 \mathrm{~m} \mathrm{~s}^{-1}$. The connection between the $R H$, the wind direction and the number fraction $(N F)$ of $50 \mathrm{~nm}$ volatile particles are shown in the exceedance 


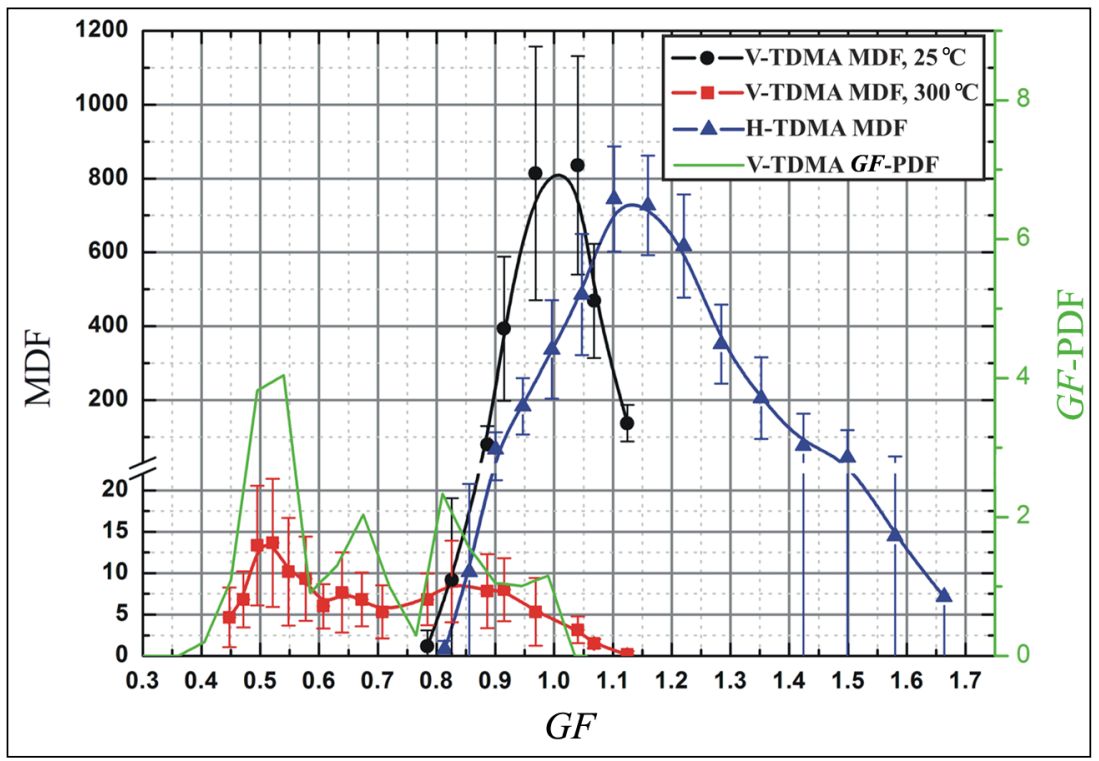

Fig. 3. Average of the measurement distribution function (MDF, left scale) (i. e. particle raw counts at the outlet of the TDMA as a function of GF set at DMA2 for a defined dry size selected with DMA1) and the growth factor probability density function (GF-PDF, right scale) for all nocturnal nucleation episodes. Bars on the red line show a Poisson counting uncertainty, black and blue lines show time variability (standard deviation) over the hours sampled.

contour plot in Fig. 4. The exceedance contour shows the wind direction and the relative humidity conditions when the $N F$ of $50 \mathrm{~nm}$ volatile particles exceeds 0.8 . The intensity of the color indicates the number of exceedance. In Section III, representing west-north winds, the $N F$ of 0.8 for $50 \mathrm{~nm}$ volatile particles were exceeded most when the $R H$ was nearly $~ 100 \%$. Other, less intense exceedance regions might also be seen in Sections I and II.

Plausible aerosol particle and precursor gas sources are indicated in Fig. 1. Those are congregation of roads, surrounding the measurement site including

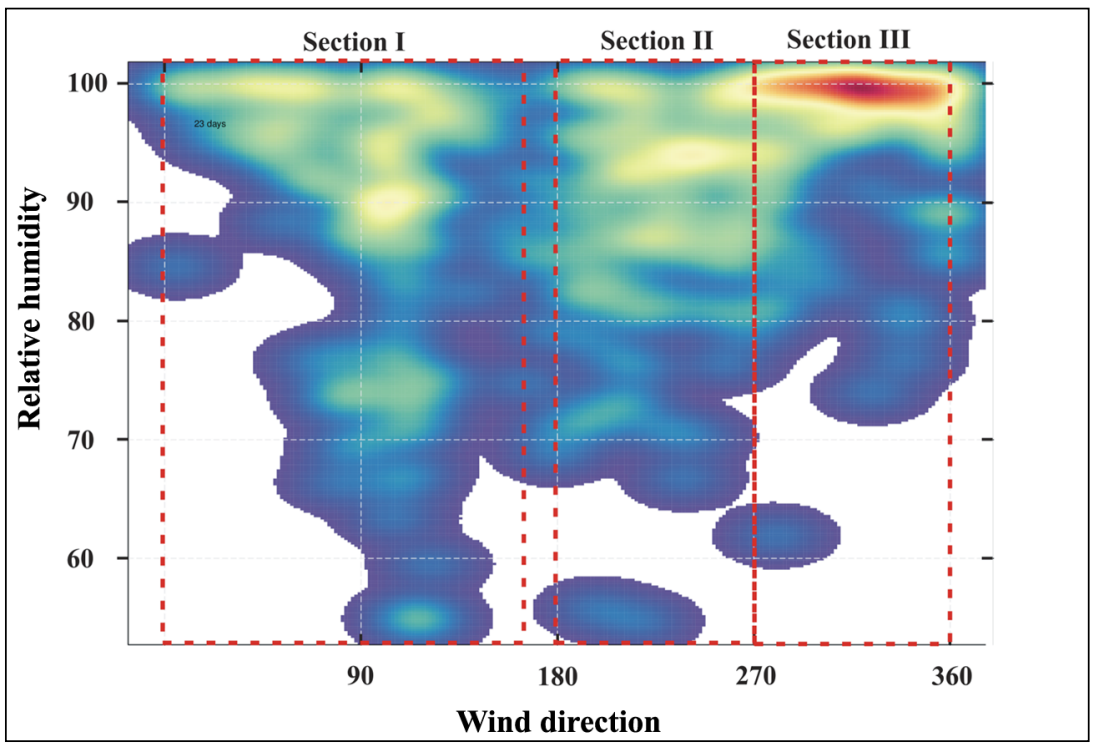

Fig. 4. Exceedance contour for all measurement period (nighttime), showing the conditions when $N F$ of $50 \mathrm{~nm}$ volatile particle fraction exceeds 0.8 . Color intensity shows the strength of exceedance. 
the provincial road with relatively low traffic load, $\sim 500 \mathrm{~m}$ to the west, the gravel road with intensive vehicle load, $200 \mathrm{~m}$ to the east, and the heavily loaded main street towards Xianghe center, $500 \mathrm{~m}$ to the south-east. A periodically smoldering dump for domestic and a small scale industrial (plastics, metal paint packages) waste, $200 \mathrm{~m}$ to the south, was a strong aerosol particle source under the right wind direction. Our measurements were conducted during summer months, thus nocturnal $\mathrm{SO}_{2}$ peaks cannot be associated with high $\mathrm{SO}_{2}$ concentrations during the heating-period observed by Ran [33], wherein details of instrumentation and measurements for $\mathrm{SO}_{2}$ as well as $\mathrm{O}_{3}$ and $\mathrm{NO}_{x}$ in Xianghe were described. However, the use of coal pellets for cooking, water heating and other use were evident around the site, which might justify the elevated nighttime $\mathrm{SO}_{2}$ concentrations when the wind came from the residential area. During the observation period, $\mathrm{NO}_{x}$ and $\mathrm{O}_{3}$ nighttime concentrations averaged at about 30 and $72 \mathrm{ppbv}$, respectively. A high peak of the $\mathrm{NO}_{x}$ concentration around $180 \mathrm{ppbv}$ was associated with local emissions and the daytime evolution of the planetary boundary layer [33]. Moreover, the cattle sheds, $100 \mathrm{~m}$ to the west (Fig. 1), might have served as a source for high concentrations of volatile amines (methylamine, dimethylamine, trimethylamine, among others) and $\mathrm{NH}_{3}$.

\subsection{Discussion}

In plumes, which are enriched with sulfur and nitrogen oxides, the $\mathrm{SO}_{2}$ to $\mathrm{H}_{2} \mathrm{SO}_{4}$ nighttime conversion was observed [34]. For the NPF pathway, where the $\mathrm{OH}$ radical $(\cdot \mathrm{OH})$ is included, it was shown that the . OH production from hydrocarbon ozonolysis reactions may play a very important role for the nighttime new particle formation [35]. On the other hand, $\mathrm{NO}_{3}$ and $\mathrm{N}_{2} \mathrm{O}_{5}$, arising from $\mathrm{NO}_{2}$ and $\mathrm{O}_{3}$, constitute an important chemical system in the nocturnal atmosphere with concentrations up to hundreds of pptv in polluted environments [36]. Dinitrogen pentoxide can serve as a significant pathway for the conversion of $\mathrm{NO}_{x}$ into nitric acid through its heterogeneous hydrolysis on aerosols. Its nocturnal oxidation capacity is believed to be as large as that one of the hydroxyl radical during the daytime [37]. In our case, the increase of the $\mathrm{NO}_{x}$ concentration positively correlates (correlation coefficient of 0.5 ) with the nucleation mode particle number concentration (Fig. 2). Studies show that ultrafine particles, composed of ammonium sulfate or sulfuric acid, grow significantly through water vapour condensation. During regional nucleation events in the urban Atlanta, the hygroscopic growth factor of $10 \mathrm{~nm}$ sized ammonium sulfate aerosol particles was 1.4 [38]. In our study, much larger particles ( $35 \mathrm{~nm}$ dry size) were figured out to be less hygroscopic ( $G F=1.15)$ (Fig. 3). Moreover, the measurement site was equally surrounded by residential areas, thus there was no reason to believe that local emissions of $\mathrm{SO}_{2}$ could depend on the wind direction, at least during the non-heating period.

CPC battery studies on the water affinity of nucleation mode particles $(2-9 \mathrm{~nm})$ suggest that freshly nucleated particles are composed of less hygroscopic compounds, presumably of organic species at the earliest steps of particle formation and growth [39]. This agrees well with our observations if we assume an abundance of amines in the surrounding air. Emissions from cattle rumen and manure are known to be abounding in volatile amines and $\mathrm{NH}_{3}$ [40]. The cattle sheds might have served as a source for high concentrations of volatile amines and $\mathrm{NH}_{3}$. Studies on the formation and composition of ultrafine particles showed that $\mathrm{NH}_{3}$ and amines are important constituents of the new particle formation process [41, 42, 43. Although we did not measure neither $\mathrm{NH}_{3}$ nor amines during our measurement campaign, the bursts in the concentration of newly formed particles were consistent with wind coming from the direction of residential areas and cattle lofts suggesting their participation in the nucleation process.

In ambient measurements, the $R H$ is considered as an indirect nucleation inhibitor, mainly because the surface area of existing particles increases due to their affinity to absorb water vapour molecules. In our study we observed that nucleation takes place with relatively high condensation sinks and $R H$. From the exceedance contour (Fig. 4), it is obvious that the $50 \mathrm{~nm}$ particle volatility greatly depends on the $\mathrm{RH}$ and the wind direction. It agrees with the theoretical models, which predict that an increasing relative humidity results in a higher nucleation rate [41].

\section{Conclusions}

Because nighttime NPF does not fit into the frame of daytime events, the lack of interest in nocturnal nucleation research casted a shadow on such phenomenon. It leads to a sparse knowledge of nocturnal nucleation forcing components. The number size distributions, volatility and hygroscopicity of aerosol particles were investigated at the North China Plain, Xianghe in the summer of 2013 to understand the influence of local sources on atmospheric processes in a better way. Nocturnal new particle formation events were observed on $59 \%$ nights of 32 measuring days in a discrete manner without pronounced subsequently 
following particle growth. Bursts of high concentrations of ultrafine particles were found, suggesting nucleation despite the high condensation sink. Results from H-TDMA and V-TDMA measurements have shown that the newly formed particles are volatile and less hygroscopic. Because of the evolution of the nighttime boundary layer, high concentrations of $\mathrm{NO}_{x}, \mathrm{NH}_{3}$ and amines might accumulate in nearby living areas and life-stock lofts. These gases were transported later to the measurement site by weak winds, and enhance the nocturnal nucleation process. New particle formation and rapid growth could have also taken place in the loft region and have been transported to the measurement site by northwest winds.

\section{Acknowledgements}

This research was supported by the projects of the Sino German Science Center (No. GZ663) and the National Basic Research Program of China (No. 2013CB228503), and the National Natural Science Foundation of China (Nos. 21190052, 41121004). Simonas Kecorius acknowledges support by the Project "Promotion of Student Scientific Activities" (VP13.1-ŠMM-01-V-02-003) from the Research Council of Lithuania. This project is funded by the Republic of Lithuania and the European Social Fund under the 2007-2013 Human Resources Development Operational Programme's priority 3.

\section{References}

[1] I. Tegen, D. Koch, A.A. Lacis, and M. Sato, Trends in tropospheric aerosol loads and corresponding impact on direct radiative forcing between 1950 and 1990: A model study, J. Geophys. Res. 105, 26971-26989 (2000), http://dx.doi.org/ 10.1029/2000JD900280

[2] X. Tie, D. Wu, and G. Brasseur, Lung cancer mortality and exposure to atmospheric aerosol particles in Guangzhou, China, Atmos. Environ. 43(14), 2375-2377 (2009).

[3] M. Kulmala, H. Vehkamaki, T. Petäjä, M. Dal Maso, A. Lauri, V.-M. Kerminen, W. Birmili, and P.H. McMurry, Formation and growth rates of ultrafine atmospheric particles: A review of observations, J. Aerosol Sci. 35, 143-176 (2004).

[4] H. Yu, R. McGraw, and S.H. Lee, Effects of amines on formation of sub-3 nm particles and their subsequent growth, Geophys. Res. Lett. 39(2), L02807 (2012).

[5] B. Wehner, A. Wiedensohler, T.M. Tuch, Z.J. Wu, M. Hu, J. Slanina, and C.S. Kiang, Variability of the aerosol number size distribution in Beijing, China: New particle formation, dust storms, and high con- tinental background, Geophys. Res. Lett. 31, L22108 (2004), http://dx.doi.org/10.1029/2004GL021596

[6] Z. Wu, M. Hu, S. Liu, B. Wehner, S. Bauer, A. Wiedensohler, et al., New particle formation in Beijing, China: Statistical analysis of a 1-year data set, J. Geophys. Res. 112(D9), D09209 (2007).

[7] J.R. Pierce, W.R. Leaitch, J. Liggio, et al., Nucleation and condensational growth to $\mathrm{CCN}$ sizes during a sustained pristine biogenic SOA event in a forested mountain valley, Atmos. Chem. Phys. 12, 3147-3163 (2012).

[8] M.J. Dunn, J.-L. Jimenez, D. Baumgardner, T. Castro, P.H. McMurry, and J.N. Smith, Measurements of Mexico City nanoparticle size distributions: Observations of new particle formation and growth, I. Geophys. Lett. 31, LI10102 (2004), http://dx.doi.org/10.1029/2004GL019483

[9] A. Wiedensohler, H.-C. Hansson, D. Orsini, et al., Night-time formation and occurrence of new particles associated with orographic clouds, Atmos. Environ. 31, 2545-2559 (1997).

[10] S.-H. Lee, L.-H. Young, D.R. Benson, et al., Observations of nighttime new particle formation in the troposphere, J. Geophys. Res. 113, D10210 (2008), http://dx.doi.org/10.1029/2007JD009351

[11] T. Suni, M. Kulmala, A. Hirsikko, et al., Formation and characteristics of ions and charged aerosol particles in a native Australian Eucalypt forest, Atmos. Chem. Phys. 8, 129-139 (2008), http:// dx.doi.org/10.5194/acp-8-129-2008

[12]M. Kulmala and A. Laaksonen, Binary nucleation of water-sulfuric acid system: Comparison of classical theories with different $\mathrm{H}_{2} \mathrm{SO}_{4}$ saturation vapor pressures, J. Chem. Phys. 93(1), 696-701 (1990).

[13]P. Korhonen, M. Kulmala, A. Laaksonen, Y. Viisanen, R. McGraw, and J.H. Seinfeld, Ternary nucleation of $\mathrm{H}_{2} \mathrm{SO}_{4}, \mathrm{NH}_{3}$, and $\mathrm{H}_{2} \mathrm{O}$ in the atmosphere, J. Geophys. Res. 104(D21), 26349-26353 (1999).

[14]N. Ma, C.S. Zhao, A. Nowak, et al., Aerosol optical properties in the North China Plain during HaChi campaign: an in-situ optical closure study, Atmos. Chem. Phys. 11, 5959-5973 (2011).

[15]I.K. Ortega, T. Suni, M. Boy, et al., New insights into nocturnal nucleation, Atmos. Chem. Phys. 12, 4297-4312 (2012), http://dx.doi.org/10.5194/acp12-4297-2012

[16]S.S. Brown, W.P. Dube, J. Peischl, et al., Budgets for nocturnal VOC oxidation by nitrate radicals aloft during the 2006 Texas Air Quality Study, J. Geophys. Res. 116, D24305 (2011), http://dx.doi. org/10.1029/2011JD016544

[17]Z.Z. Deng, C.S. Zhao, N. Ma, et al., Size-resolved and bulk activation properties of aerosols in the North China Plain, Atmos. Chem. Phys. 11, 38353846 (2011), http://dx.doi.org/10.5194/acp-11 $3835-2011$ 
[18] L. Wang, J. Yang, P. Zhang, et al., A review of air pollution and control in Hebei Province, China, Open J. Air Pollut. 2(03), 47 (2013).

[19] T.M. Tuch, A. Haudek, T. Muller, A. Nowak, H. Wex, and A. Wiedensohler, Design and performance of an automatic regenerating adsorption aerosol dryer for continuous operation at monitoring sites, Atmos. Meas. Tech. 2, 417-422 (2009).

[20] A. Wiedensohler, W. Birmili, A. Nowak, et al., Mobility particle size spectrometers: harmonization of technical standards and data structure to facilitate high quality long-term observations of atmospheric particle number size distributions, Atmos. Meas. Tech. 5, 657-685 (2012).

[21]S. Mirme and A. Mirme, The mathematical principles and design of the NAIS - a spectrometer for the measurement of cluster ion and nanometer aerosol size distributions, Atmos. Meas. Tech. 6(4), 1061-1071 (2013).

[22] M. Kulmala, I. Riipinen, M. Sipilä, et al., Toward direct measurement of atmospheric nucleation, Science 318(5847), 89-92 (2007).

[23] A. Massling, S. Leinert, A. Wiedensohler, and D. Covert, Hygroscopic growth of sub-micrometer and one-micrometer aerosol particles measured during ACE-Asia, Atmos. Chem. Phys. 7(12), 3249-3259 (2007).

[24] I.N. Tang and H.R. Munkelwitz, Water activities, densities, and refractive indices of aqueous sulfates and sodium nitrate droplets of atmospheric importance, J. Geophys. Res. 99(D9), 18801-18808 (1994).

[25] S. Philippin, A. Wiedensohler, and F. Stratmann, Measurements of non-volatile fractions of pollution aerosols with an eight-tube volatility tandem differential mobility analyzer (VTDMA-8), J. Aerosol Sci. 35(2), 185-203 (2004).

[26]H. Burtscher, U. Baltensperger, N. Bukowiecki, et al., Separation of volatile and non-volatile aerosol fractions by thermodesorption: instrumental development and applications, J. Aerosol Sci. 32(4), 427-442 (2001).

[27] M. Dal Maso, M. Kulmala, I. Riipinen, R. Wagner, T. Hussein, P.P. Aalto, and K.E. Lehtinen, Formation and growth of fresh atmospheric aerosols: eight years of aerosol size distribution data from SMEAR II, Hyytiala, Finland, Boreal Environ. Res. 10(5), 323 (2005).

[28] Y.F. Cheng, M. Berghof, R.M. Garland, et al., Influence of soot mixing state on aerosol light absorption and single scattering albedo during air mass aging at a polluted regional site in northeastern China, J. Geophys. Res. 114, D00G10 (2009), http://dx.doi.org/10.1029/2008jd010883

[29] W. Birmili, F. Stratmann, A. Wiedensohler, D. Covert, L.M. Russell, and O. Berg, Determination of differential mobility analyzer transfer functions using identical instruments in series, Aerosol Sci. Technol. 27(2), 215-223 (1997).

[30] M. Gysel, G.B. McFiggans, and H. Coe, Inversion of tandem differential mobility analyser (TDMA) measurements, J. Aerosol Sci. 40(2), 134-151 (2009).

[31] H.E. Manninen, T. Nieminen, I. Riipinen, et al., Charged and total particle formation and growth rates during EUCAARI 2007 campaign in Hyytiälä, Atmos. Chem. Phys. 9(12), 4077-4089 (2009).

[32] J. Heintzenberg, B. Wehner, and W. Birmili, 'How to find bananas in the atmospheric aerosol': new approach for analyzing atmospheric nucleation and growth events, Tellus B 59(2), 273-282 (2007).

[33] L. Ran, W-L. Lin, P-C. Wang, and Z-Z. Deng, Surface trace gases at a rural site between the megacities of Beijing and Tianjin, Atmos. Ocean. Sci. Lett. 7(3), 230 (2014).

[34] S.S. Brown, T.B. Ryerson, A.G. Wollny, et al., Variability in nocturnal nitrogen oxide processing and its role in regional air quality, Science 311(5757), 67-70 (2006).

[35] N.M. Donahue, J.H. Kroll, J.G. Anderson, and K.L. Demerjian, Direct observation of $\mathrm{OH}$ production from the ozonolysis of olefins, Geophys. Res. Lett. 25(1), 59-62 (1998).

[36] S.S. Brown, H. Stark, T.B. Ryerson, et al., Nitrogen oxides in the nocturnal boundary layer: $\mathrm{Si}$ multaneous in situ measurements of $\mathrm{NO}_{3}, \mathrm{~N}_{2} \mathrm{O}_{5}$, $\mathrm{NO}_{2}, \mathrm{NO}$, and $\mathrm{O}_{3}$, J. Geophys. Res. 108(D9), 4299 (2003).

[37] A. Geyer, B. Alicke, S. Konrad, T. Schmitz, J. Stutz, and U. Platt, Chemistry and oxidation capacity of the nitrate radical in the continental boundary layer near Berlin, J. Geophys. Res. 106(D8), 80138025 (2001).

[38] H. Sakurai, M.A. Fink, P.H. McMurry, L. Mauldin, K.F. Moore, J.N. Smith, and F.L. Eisele, Hygroscopicity and volatility of 4-10 $\mathrm{nm}$ particles during summertime atmospheric nucleation events in urban Atlanta, J. Geophys. Res. 110, D22504 (2005).

[39] R. Zhang, A. Khalizov, L. Wang, M. Hu, and W. Xu, Nucleation and growth of nanoparticles in the atmosphere, Chem. Rev. 112(3), 1957-2011 (2011).

[40] U. Kuhn, J. Sintermann, C. Spirig, M. Jocher, C. Ammann, and A. Neftel, Basic biogenic aerosol precursors: Agricultural source attribution of volatile amines revised, Geophys. Res. Lett. 38(16), L16811 (2011).

[41] T. Berndt, F. Stratmann, M. Sipilä, et al., Laboratory study on new particle formation from the reaction $\mathrm{OH}+\mathrm{SO}_{2}$ : influence of experimental conditions, $\mathrm{H}_{2} \mathrm{O}$ vapour, $\mathrm{NH}_{3}$ and the amine tert-butylamine on the overall process, Atmos. Chem. Phys. 10(15), 7101-7116 (2010).

[42] M.E. Erupe, A.A. Viggiano, and S.H. Lee, The effect of trimethylamine on atmospheric nucleation 
involving $\mathrm{H}_{2} \mathrm{SO}_{4}$, Atmos. Chem. Phys. 11(10), 4767-4775, (2011).

[43] H. Yu, R. McGraw, and S.H. Lee, Effects of amines on formation of sub-3 $\mathrm{nm}$ particles and their sub- sequent growth, Geophys. Res. Lett. 39(2), L02807 (2012).

\title{
NAKTINIS AEROZOLIO DALELIUU SUSIDARYMAS ŠIAURINĖJE KINIJOS LYGUMOJE
}

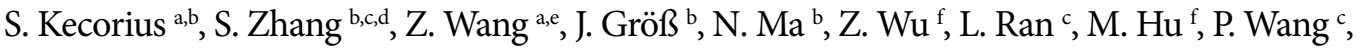 \\ V. Ulevičius ${ }^{\mathrm{a}}$, A. Wiedensohler ${ }^{\mathrm{b}}$ \\ ${ }^{a}$ Valstybinis mokslinių tyrimų institutas Fiziniu ir technologijos mokslu centras, Vilnius, Lietuva \\ ${ }^{\mathrm{b}}$ Leibnico troposferos tyrimu institutas, Leipcigas, Vokietija \\ ${ }^{c}$ Kinijos mokslų akademijos Atmosferos fizikos institutas, Pekinas, Kinija \\ ${ }^{\mathrm{d}}$ Čengdu informacijos technologijos universitetas, Čengdu, Kinija \\ e Makso Planko chemijos institutas, Maincas, Vokietija \\ ${ }^{\mathrm{f}}$ Pekino universiteto Aplinkos mokslų ir inžinerijos koledžas, Pekinas, Kinija
}

\section{Santrauka}

2013 m. liepos mèn. Sianghe mieste (Hebėjaus provincija, Kinija) vykdytų išskirtinių aerozolio dalelių fizikinių-cheminių savybių tyrimų metu buvo tirtas retas naktinis dalelių susidarymas ir ji lemiančios priežastys. Panaudojus moderniausią spektrometrinę aerozolio dalelių matavimo ịrangą nustatyta, kad naujų dalelių susidarymas vyko esant aukštam kondensaciniam nuotèkiui, $C S=0,055 \mathrm{~s}^{-1}$, dalelių susidarymo sparta naktį buvo 1,25 kartus didesnè nei dieną, siekė $45 \pm 5 \mathrm{~cm}^{-3} \mathrm{~s}^{-1}$. Naujų dalelių susidarymo metu skaitinè 2-10 $\mathrm{nm}$ dydžio dalelių koncentracijos reikšmè padidejo nuo $N_{2-10 \mathrm{~nm}}=2,0 \cdot 10^{4} \pm 2000 \mathrm{~cm}^{-3} \mathrm{iki}$ $N_{2-10}=7,3 \cdot 10^{4} \pm 7300 \mathrm{~cm}^{-3}$. Naujai susidariusios 20-35 nm dydžio dalelès pasižymèjo itin dideliu la-
\end{abstract}

kumu ir mažu higroskopiškumu. Po dalelių išgarinimo $300{ }^{\circ} \mathrm{C}$ temperatūroje buvo užregistruota tik smulki liekamoji frakcija antrojo diferencialinio daleliu judrio analizatoriaus išèjime. Ši frakcija siejama su dalelèse vykstančiu polimerizacijos vyksmu, kai ant jos paviršiaus kondensuojasi organiniai junginiai. Naujai susiformavusių aerozolio dalelių populiacija, patekusi ¡ $87 \%$ santykinès oro drégmès kamerą, augo vienodai ir pasižymejo $G F=1,15$ augimo koeficientu. Atlikus vietovès galimų šaltinių analizę nustatyta, kad naktinis naujų dalelių susidarymas yra nulemtas aukštos santykinès oro drègmès (>98\%), vejo krypties ir iš gyvenamųjų teritorijų atnešamų lakiosios organikos (amino) ir $\mathrm{NH}_{3}$ junginių. 